\title{
The political economy of unsustainable lock-ins in North American commodity agriculture: a path forward - Response to Struckman
}

\author{
Silvia Secchi \\ Department of Geographical and Sustainability Sciences, University of Iowa, USA, \\ silvia-secchi@uiowa.edu
}

\begin{abstract}
In this commentary, I argue that in North America, the overuse of synthetic nitrogen fertilizer is due to institutional and technological lock-ins, which are the result of historical policies with deep roots in an agricultural system focused on increasing production of commodities with disregard for their full social costs. Further, excessive fertilizer use is integral to production systems that have disconnected crop and livestock production to the extent that manure is a waste product, which further creates environmental problems. In order to address the environmental and social problems associated with industrial agriculture, it will be necessary to bring market prices closer to true social costs, thereby eliminating overproduction of commodity grains and oilseeds, and to promote more diverse agricultural landscapes.
\end{abstract}

Keywords: synthetic nitrogen fertilizer; technological and institutional lock-in; fertilizer management; agri-environmental policies; sustainability transition

I wholeheartedly agree with Luke Struckman's assessment that the overuse of synthetic nitrogen fertilizer is due to institutional and technological lock-ins. Here I trace the historical roots of the lock-ins, and their systemic linkages with other components of industrial agriculture, particularly livestock production and exports. I argue that the solution to the dual crisis of farm consolidation and environmental degradation in North America requires decoupling subsidies from agricultural production and fully considering the environmental costs of industrial agriculture.

\section{The past}

The overproduction treadmill in North America originates in the practices of settler colonialism (Phillips 1999; Rotz 2017). The Canadian and U.S. governments allocated land to settlers not just as if no Native people lived there, via mass removal and genocide, but also with disregard for the physical environment and its capacity to sustain crop production. As a result, settler agriculture caused environmental problems from its inception, which culminated in the Dust Bowl (Baker et al. 1993; Phillips 1999; Mutel 2008). Subsequent policies such as Roosevelt's New Deal still focused on crop production, with conservation policies being deployed as dual-goal activities that were supposed to simultaneously reduce production levels - thereby increasing prices - and improve environmental quality (Holland et al. 2020; Cochrane 1979).

The historical central policy problem in North American agriculture is the tension 
between production and market prices, and how to ensure adequate income for settler farmers given that overproduction depresses prices. Environmental considerations are ancillary to this core issue. Canada's solution to this problem has been bifurcated: supply management measures are used for products that are not exported such as dairy, whereby the prices are guaranteed by production quotas, while subsidies, in the form of direct payments and crop insurance subsidies linked to production levels, are used for export commodities. In the US, a major agricultural exporter, subsidies are the policy of choice to guarantee income stability. Since agriculture in both countries depends on exports to thrive, and governments reduce or eliminate downside risks when prices are low via subsidies, the overall system is geared to reward higher production - particularly on the intensive margin, via increased yields, as Luke Struckman notes in his intervention. The institution of land grant universities in the United States under the 1862 Morrill Act, not accidentally linked to a massive land expropriation from Native Americans (Lee \& Ahtone 2020), created a Research and Development (R\&D) infrastructure that has, to this day, promoted increased yields as a cornerstone of successful North American agriculture.

While the foundations of the overproduction treadmill go back to the middle $19^{\text {th }}$ Century, the process accelerated after WWII. During the war, many underemployed people living on farms left for manufacturing jobs - so farm employment declined drastically and never went back up. At the same time, all the technological innovations that had been developed by USDA and the Land Grant universities but were too expensive for farmers in the 1930s were adopted in large numbers: rubber tires on tractors, disk plows, corn and cotton pickers, automated cow milking - there were so many innovations being adopted that they amounted to a "mechanical revolution in farming" (Cochrane 1979). This was accompanied by biological and chemical revolutions as well: use of drugs and vaccines in livestock, hybrid seeds and commercial fertilizers. This was specifically the case for nitrogen. Though the HaberBosch process to produce artificial nitrogen fertilizer had been invented in 1908, its use became widespread after the end of WWII, when many chemical factories used to produce explosives could be repurposed (Russel \& Williams 1977). These combined changes meant that farmers were buying many more inputs in commercial markets while the roles of human labor and animals were greatly reduced. Because manure was no longer necessary to fertilize crops, this initiated the separation between crop and livestock production, which has resulted, less than a century later, in Confined Animal Feeding Operations with hundreds of thousands of chickens and tens of thousands of hogs sold per operation (MacDonald $\&$ McBride 2009), and has made manure a waste product, rather than a complement or substitute to artificial fertilizers. This has caused extensive water quality problems in the North American continent for both fresh and saltwater systems (Jones et al. 2018; Hoorman et al. 2008; Brooker et al. 2018; Long et al. 2018). At the same time, crop yields continue increasing, albeit at different paces, and with different environmental costs (Grassini et al. 2013; Hunter et al. 2017).

In North America, the solution to the ever-expanding granary, and associated depressed prices, has been to shore up prices via new demand sources such as 
biofuels and export markets, while creating price floors for farmers with a variety of subsidy programs. These price floors are capitalized in rental rates and land prices, causing them to increase (Latruffe \& Le Mouël 2009; Goodwin et al. 2011). High land values create very high barriers to entry for beginning and young farmers (Key \& Lyons 2019; Weber \& Key 2014), and further concentrates wealth in the hands of larger farmers (Weber \& Key 2014).

Environmental policies in North America are ancillary - their role is to address the environmental consequences of the overproduction while providing farmers with more income (Holland et al. 2020). Thus, I argue that recognizing the deep roots of the historical lock-in effects, and their consequences on rural landscapes, is critical to creating viable sustainable agricultural solutions.

\section{A more sustainable and just future}

The policies needed to incentivize a more sustainable use of artificial fertilizers are central to promoting a more sustainable agricultural production system in North America. Fully pricing artificial fertilizer to incorporate its environmental costs would reduce its overuse and help reduce the overproduction of grains and oilseeds. Such an outcome could be achieved via a tradeable permit system or Pigouvian taxes (Von Blottnitz et al. 2006). Revenues from the tax or the auction of tradeable permits could offset subsidies to promote a more sustainable and diverse agriculture, or, if the permits were to be freely given away, their distribution would decrease the costs of the policy for current farmers (Kampas
\& White 2003), and make it more palatable.

An indirect but critical impact of fully pricing fertilizer use would be that manure would become a more attractive alternative (Sheriff 2005). This would increase the efficiency of its use. Similarly, fully pricing livestock produced in confined systems would create incentives to re-integrate livestock in the landscape and increase the demand for pasture, thereby decreasing grain and oilseed production as well. A recent contribution to the literature which I co-authored details various other complementary changes, such as

"incorporating small grains and/ or forage
crops into extended rotations; replacing some
input-intensive corn-soybean acres with peren-
nial bioenergy crops, including agroforestry;
[...] horticultural food crops; and/ or in-
creased use of edge of field nutrient loss reduc-
tion practices targeted to less productive, highly
vulnerable lands" (Prokopy et al. 2020).

As part of a policy agenda to promote a more sustainable agriculture, public funding could be de-coupled from production and redirected to promote a more diverse landscape, in terms of production, as detailed above, but by providing increased funding to support beginning and young farmers. The recent European Union's Common Agricultural Policy (CAP) reforms, which are making strides in this direction, show that such approaches are politically feasible (Blandford \& Matthews 2019), even if still perfectible (Pe'er et al. 2019; Dupraz \& Guyomard 2019).

Addressing the historical production and environmental imbalances in North America commodity agriculture and "unlocking" institutions and technologies to promote a more sustainable system is not 
impossible - regardless of what entrenched interests argue, the massive amounts of public funds being regularly expended to maintain such an inefficient and inequitable system offer a lever to affect change. In the US, as of 2012-2014, white people own $98 \%$ and operate $94 \%$ of farmland (Horst \& Marion 2019). In Canada, the Census of Agriculture does not collect information on race and ethnicity of operators, but data on mother tongues and country of birth indicate most Canadian farmers are white (Rotz et al. 2019).

In the US alone, in the last two years, farmers have received tens of billions of dollars in aid which, on aggregate, have more than compensated them for short term trade losses (Janzen \& Hendricks 2020). This is not just an environmentally and socially unsustainable system - its economics are broken as well.

To help "unlock" new technologies and institutions, it is critical to reframe the public's view of commodity agriculture as a sector dependent on continuing subsidies, publicly funded R\&D and benefiting a wealthy, small and shrinking group of farmers. Agriculture must transform from an exceptional sector - subject to different rules than all other economic sectors (Alons 2017). This will require moving away from "the belief system that provides [its] cognitive justification and political legitimation" (Daugbjerg \& Feindt 2017).

\section{References}

Alons, G. (2017). Environmental policy integration in the EU's common agricultural policy: greening or greenwashing? Journal of European Public Policy 24:11, 1604-1622. DOI: 10.1080/13501763.2017.1334085.

Baker, R.G., D.P. Schwert, E.A. Bettis, \& C.A. Chumbley (1993). Impact of Euro-American settlement on a riparian landscape in northeast lowa, midwestern USA: an integrated approach based on historical evidence, floodplain sediments, fossil pollen, plant macrofossils and insects. The Holocene 3:4, 314-323. DOI: $10.1177 / 095968369300300403$.

Blandford, D. \& A. Matthews (2019). EU and US Agricultural Policies: Commonalities and Contrasts. EuroChoices 18:1), 4-10. DOI: https:// DOI.org/10.1111/1746-692X.12217.

Brooker, M. R., K. Longnecker, E. B. Kujawinski, M. H. Evert \& P. J. Mouser (2018). Discrete Organic Phosphorus Signatures are Evident in Pollutant Sources within a Lake Erie Tributary. Environmental Science \& Technology 52:12, 6771-6779. DOI: 10.1021/acs.est.7b05703.

Cochrane, W. W. (1979). The development of American agriculture: $A$ historical analysis. Minneapolis: University of Minnesota Press.

Daugbjerg, C., \& P. H. Feindt (2017). Post-exceptionalism in public policy: transforming food and agricultural policy. Journal of European Public Policy 24:11, 1565-1584. DOI: 10.1080/13501763.2017.1334081.

Dupraz, P., \& H. Guyomard (2019). Environment and Climate in the Common Agricultural Policy. EuroChoices 18:1, 18-25. DOI: https://DOI. org/10.1111/1746-692X.12219.

Goodwin, B. K., A. K. Mishra \& F. Ortalo-Magné (2011). The buck stops where? The distribution of agricultural subsidies. National Bureau of Economic Research. DOI 10.3386/w16693

Grassini, P., K. M. Eskridge \& K. G. Cassman (2013). Distinguishing between yield advances and yield plateaus in historical crop production trends. $\mathrm{Na}$ ture Communications 4:1, 2918. DOI: 10.1038/ ncomms3918.

Holland, A., D. Bennett \& S. Secchi (2020). Complying with conservation compliance? An assessment of recent evidence in the US Corn Belt. Environmental Research Letters 15:8, 084035. DOI: 10.1088/1748-9326/ab8f60.

Hoorman, J., T. Hone, T. Sudman, T. Dirksen, J. Iles \& K. R. Islam (2008). Agricultural Impacts on Lake and Stream Water Quality in Grand Lake St. Marys, Western Ohio. Water, Air, and Soil Pollution 193:1, 309-322. DOI: 10.1007/ s11270-008-9692-1.

Horst, M., \& A. Marion (2019). Racial, ethnic and gender inequities in farmland ownership and farming in the U.S. Agriculture and Human Values 36:1, 1-16. DOI: 10.1007/s10460-018-9883-3.

Hunter, M. C., R. G. Smith, M. E. Schipanski, L. W. Atwood \& D. A. Mortensen (2017). Agriculture in 2050: Recalibrating Targets for Sustainable Intensification. BioScience 67:4, 386-391. DOI: 
10.1093/biosci/bix010.

Janzen, J. P., \& N. P. Hendricks (2020). Are Farmers Made Whole by Trade Aid? Applied Economic Perspectives and Policy 42:2, 205-226. DOI: https://DOI.org/10.1002/aepp.13045.

Jones, C. S., C. W. Drake, C. E. Hruby, K. E. Schilling \& C. F. Wolter (2018). Livestock manure driving stream nitrate. Ambio 48, 1143-1153. DOI: 10.1007/s13280-018-1137-5.

Kampas, A., \& B. White (2003). Selecting permit allocation rules for agricultural pollution control: a bargaining solution. Ecological Economics 47:2, 135-147. DOI: https://DOI.org/10.1016/S09218009(03)00195-2.

Key, N., \& G. Lyons (2019). An overview of beginning farms and farmers: Economic Brief Number 29. USDA Economic Research Service.

Latruffe, L., \& C. Le Mouël (2009). Capitalization of government support in agricultural land prices: what do we know? Journal of Economic Surveys 23:4, 659-691. DOI: https://DOI.org/10.1111/ j.1467-6419.2009.00575.x.

Lee, R., \& T. Ahtone (2020). Land-grab universities. Expropriated indigenous land is the foundation of the land-grant university system. High Country News, March 30, 2020. https://www.hen.org/ issues/52.4/indigenous-affairs-education-land-grab-universities.

Long, C. M., R. Logsdon Muenich, M. M. Kalcic \& D. Scavia (2018). Use of manure nutrients from concentrated animal feeding operations. Journal of Great Lakes Research 44:2, 245-252. DOI: https://DOI.org/10.1016/j.jglr.2018.01.006.

MacDonald, J. M. \& W. D. McBride (2009). The transformation of US livestock agriculture scale, efficiency, and risks: Economic Information Bulletin 43. United States Department of Agriculture, Economic Research Service.

Mutel, C. F. (2008). The emerald horizon: The history of nature in lowa. lowa City: University of lowa Press.

Pe'er, G., Y. Zinngrebe, F. Moreira, C. Sirami, S. Schindler, R. Müller, V. Bontzorlos, D. Clough, P. Bezák, A. Bonn, B. Hansjürgens, A. Lomba, S. Möckel, G. Passoni, C. Schleyer, J. Schmidt \& S. Lakner (2019). A greener path for the EU Common Agricultural Policy. Science 365:6452, 449-451. DOI: 10.1126/science.aax3146.

Phillips, S. T. (1999). Lessons from the Dust Bowl: Dryland Agriculture and Soil Erosion in the United States and South Africa, 1900-1950. Environmental History 4:2, 245-266. DOI: $10.2307 / 3985305$

Prokopy, L. S., B. M. Gramig, A. Bower, S. P. Church, B. Ellison, P. W. Gassman, K. Genskow, D. Gucker, S. G. Hallett, J. Hill, N. Hunt, K. A. Johnson, I.
Kaplan, J. P. Kelleher, H. Kok, M. Komp, P. Lammers, S. LaRose, M. Liebman, A. Margenot, D. Mulla, M. J. O'Donnell, A. W. Peimer, E. Reaves, K. Salazar, C. Schelly, K. Schilling, S. Secchi, A. D. Spaulding, D. Swenson, A. W. Thompson \& J. D. Ulrich-Schad (2020). The urgency of transforming the Midwestern U.S. landscape into more than corn and soybean. Agriculture and Human Values 37:3, 537-539. DOI: 10.1007/ s10460-020-10077-x.

Rotz, S. (2017). 'They took our beads, it was a fair trade, get over it': Settler colonial logics, racial hierarchies and material dominance in Canadian agriculture. Geoforum 82: 158-169. DOI: https:// DOI.org/10.1016/j.geoforum.2017.04.010.

Rotz, S., E. D. G. Fraser \& R. C. Martin (2019). Situating tenure, capital and finance in farmland relations: implications for stewardship and agroecological health in Ontario, Canada. The Journal of Peasant Studies 46:1, 142-164. DOI: 10.1080/03066150.2017.1351953.

Russel, D. A. \& G. G. Williams (1977). History of chemical fertilizer development. Soil Science Society of America Journal 41:2, 260-265.

Sheriff, G. (2005). Efficient waste? Why farmers over-apply nutrients and the implications for policy design. Review of Agricultural Economics 27:4, 542-557.

Von Blottnitz, H., A. Rabl, D. Boiadjiev, T. Taylor \& S. Arnold (2006). Damage costs of nitrogen fertilizer in Europe and their internalization. Journal of Environmental Planning and Management 49:3, 413-433.

Weber, J. G. \& N. Key (2014). Do Wealth Gains from Land Appreciation Cause Farmers to Expand Acreage or Buy Land? American Journal of Agricultural Economics 96:5, 1334-1348. 